\title{
Subspecific Status of the Korean Tiger Inferred by Ancient DNA Analysis
}

\author{
Mu-Yeong Lee ${ }^{1,2}$, Jee Yun Hyun ${ }^{1}$, Seo-Jin Lee ${ }^{1}$, Junghwa An ${ }^{1,3}$, Eunok Lee ${ }^{1}$, \\ Mi-Sook Min ${ }^{1}$, Junpei Kimura ${ }^{1}$, Shin-ichiro Kawada ${ }^{4}$, Nozomi Kurihara ${ }^{4}$, \\ Shu-Jin Luo ${ }^{5}$, Stephen J. O'Brien², Warren E. Johnson², Hang Lee ${ }^{1, *}$ \\ ${ }^{1}$ Conservation Genome Resource Bank for Korean Wildlife, Research Institute for Veterinary Science and \\ College of Veterinary Medicine, Seoul National University, Seoul 151-742, Korea \\ ${ }^{2}$ Laboratory of Genomic Diversity, National Cancer Institute, Frederick, MD 21072-1201, USA \\ ${ }^{3}$ Planning Office of National Ecological Institute, Ministry of Environment, Gwacheon 427-729, Korea \\ ${ }^{4}$ Department of Zoology, National Museum of Nature and Science, \\ 4-1-1, Amakubo, Tsukuba, Ibaraki 305-0005, Japan \\ ${ }^{5}$ Center for Life Sciences, School of Life Sciences, Peking University, Beijing 100871, China
}

\begin{abstract}
The tiger population that once inhabited the Korean peninsula was initially considered a unique subspecies (Panthera tigris coreensis), distinct from the Amur tiger of the Russian Far East (P. t. altaica). However, in the following decades, the population of P. t. coreensis was classified as P.t. altaica and hence forth the two populations have been considered the same subspecies. From an ecological point of view, the classification of the Korean tiger population as $P$. t. altaica is a plausible conclusion. Historically, there were no major dispersal barriers between the Korean peninsula and the habitat of Amur tigers in Far Eastern Russia and northeastern China that might prevent gene flow, especially for a large carnivore with long-distance dispersal abilities. However, there has yet to be a genetic study to confirm the subspecific status of the Korean tiger. Bone samples from four tigers originally caught in the Korean peninsula were collected from two museums in Japan and the United States. Eight mitochondrial gene fragments were sequenced and compared to previously published tiger subspecies' mtDNA sequences to assess the phylogenetic relationship of the Korean tiger. Three individuals shared an identical haplotype with the Amur tigers. One specimen grouped with Malayan tigers, perhaps due to misidentification or mislabeling of the sample. Our results support the conclusion that the Korean tiger should be classified as P. t. altaica, which has important implications for the conservation and reintroduction of Korean tigers.
\end{abstract}

Keywords: Panthera tigris coreensis, phylogenetic relationship, mitochondrial DNA, Korean tiger, Panthera tigris altaica, Amur tiger

\section{INTRODUCTION}

The tiger, Panthera tigris, is one of the most endangered species in the world. In the 1900s, an estimated 100,000 tigers inhabited much of the Asian continent. However, today only 3,000 survive in limited areas (Driscoll et al., 2009; Tilson and Nyhus, 2010). Tigers have been traditionally classified into eight subspecies based upon geographic distribution and morphological differences. Recently a comprehensive molecular analysis of a tiger subspecies using mtDNA and microsatellite genotypes affirmed the distinctiveness of these sub- species and identified a new subspecies, the Malayan tiger, P. t. jacksoni (Luo et al., 2004, 2008). Of these recognized subspecies, three are extinct, $P$. t. sondica, $P$. t. balica, and P. t. virgata (Driscoll et al., 2009) and one, P. t. amoyensis, only survives in zoos (Tilson et al., 2004; Morell, 2007; Luo et al., 2008).

From the Joseon Dynasty to the Japanese colonial period, tigers were seen as a threat to the Korean people and there was a lot of pressure to eliminate tigers from the wild (Endo, 2009; Kim and Lee, 2011). As a consequence, tigers that had once roamed the forests of the Korean peninsula became

\footnotetext{
(C) This is an Open Access article distributed under the terms of the Creative Commons Attribution Non-Commercial License (http://creativecommons.org/ licenses/by-nc/3.0/) which permits unrestricted non-commercial use, distribution, and reproduction in any medium, provided the original work is properly cited.

*To whom correspondence should be addressed

Tel: 82-2-880-1274, Fax: 82-2-888-2754

E-mail: hanglee@snu.ac.kr 
Table 1. Samples used in this study and haplotypes of the mitochondrial DNA

\begin{tabular}{|c|c|c|c|c|c|}
\hline Museum ID & Provider & Type of sample & Collector (the year of date) & Mt DNA haplotypes & Haplotype ID \\
\hline 10146 & $\begin{array}{l}\text { National Museum of } \\
\text { Nature and Science }\end{array}$ & Bone & Maeda Kenkiohi & Panthera tigris altaica & KOR1 \\
\hline A49797 & $\begin{array}{l}\text { National Museum of } \\
\text { Natural History }\end{array}$ & Bone & Lord W Smith (1904) & P. t. altaica & KOR2 \\
\hline A49798 & $\begin{array}{l}\text { National Museum of } \\
\text { Natural History }\end{array}$ & Bone & Lord W Smith (1904) & P. t. altaica & KOR3 \\
\hline A49799 & $\begin{array}{l}\text { National Museum of } \\
\text { Natural History }\end{array}$ & Bone & Lord W Smith (1904) & $\begin{array}{l}\text { P. t. corbetti II } \\
\text { (P. t. jacksoni) }\end{array}$ & KOR4 \\
\hline
\end{tabular}

KOR, Korean sample.

extinct and the only surviving population in the extreme northeastern Asia is the Amur or Siberian tigers in Russian Far East and northeast China.

The tiger is an animal of great significance in Korea. It is deeply embedded in the Korean history and culture with references found in numerous myths, folk tales, art work, and old sayings. Although extinct in the wild, the tiger lives on in the minds of the Korean people through the use of tiger symbols in logos and signs that represent Korea. Currently, the lack of tigers as a top predator has resulted in an uncontrolled population growth of large ungulates such as deer and wild boar causing both property damage and injuries around the country. Despite the continued attention to the tiger in Korea, there is a lack of scientific data to understand the evolutionary history of the species in this region.

There has been significant debate as to whether the tigers that once inhabited the Korean peninsula are indeed the same subspecies as the tigers that survives in the Russian Far East. In the early 20th century, Brass (1904) classified the Korean tiger as $P$. $t$. coreensis based on the morphological differences between Korean and the Amur tigers (fur color and pattern). Until 1965, CITES categorized the Korean tiger as an independent subspecies, P. t. coreensis. However, after 1965 the Korean tigers were reclassified as the same subspecies as the Amur tiger, $P$. t. altaica, without scientific confirmation. In the present study, the phylogenetic relationship of the Korean tiger was investigated by comparing data from ancient DNA samples with previously published sequences of other tiger subspecies. Accurate understanding of the subspecies status of the Korean tiger is essential to establish conservation units and to help inform future efforts to reintroduce tigers back in Korea.

\section{MATERIALS AND METHODS}

Korean tigers were extirpated from the wild and some of the remains such as bones and skins were scattered around the world. To acquire specimens with reliable records on capture locality, collector, and year of capture, an intensive survey of known collections was conducted. Four specimens were found from two museums; one in the National Science Museum, Tokyo (NSMT), Japan and three in the National Museum of Natural History (NMNH) in Washington, DC, USA (Table 1). The information regarding their origin was crosschecked using several independent references. Chung (1978) reported that an American doctor, William Lord Smith, while visiting Korea caught wild boar, roe deer, and three tigers near Mokpo in 1902. In addition, there is a record that Dr. Smith hunted three tigers from the southwestern peninsula of Korea; two tigers by himself and one by his hunter (Hollister, 1912). According to the records of the NMNH, Smith collected samples from Korea in 1904 then donated the specimens to the NMNH in 1906. Even though there is a conflict between the times of specimen collection, all records indicate that the three tigers in the $\mathrm{NMNH}$ were captured by Smith in Korea. The single specimen in the NMNS was taken over from Tokyo museum in 1989, which was initially collected by Maeda Kenkichi who lived in Korea from 1878 to 1887 (Dajokan, 1880).

DNA extraction was carried out in a dedicated ancient DNA laboratory in the Laboratory of Genomic Diversity (LGD), Frederick, USA and replicated at the Conservation Genome Resource Bank for Korean Wildlife(CGRB), Seoul, South Korea. Whole genomic DNA was isolated in multiple extracts using QIAamp DNA Micro Kit (Cat. No. 56304; Qiagen, Valencia, CA, USA) according to the manufacturer's protocol. Multiple extracts from each individual were used to confirm the consistency of ancient DNA from contamination and to facilitate PCR of ancient material. In accordance with the procedure of Driscoll et al. (2009), five mitochondrial genes (ND2, COI, ND5, ND6, and Cyt b) were amplified in eight short fragments using eight sets of primers, including a negative control. Sequences were determined in forward and reverse directions from independent amplifications and multiple extracts. 
Mu-Yeong Lee, Jee Yun Hyun, Seo-Jin Lee, Junghwa An, Eunok Lee, Mi-Sook Min, Junpei Kimura, Shin-ichiro Kawada, Nozomi Kurihara, Shu-Jin Luo, Stephen J. O'Brien, Warren E. Johnson, Hang Lee

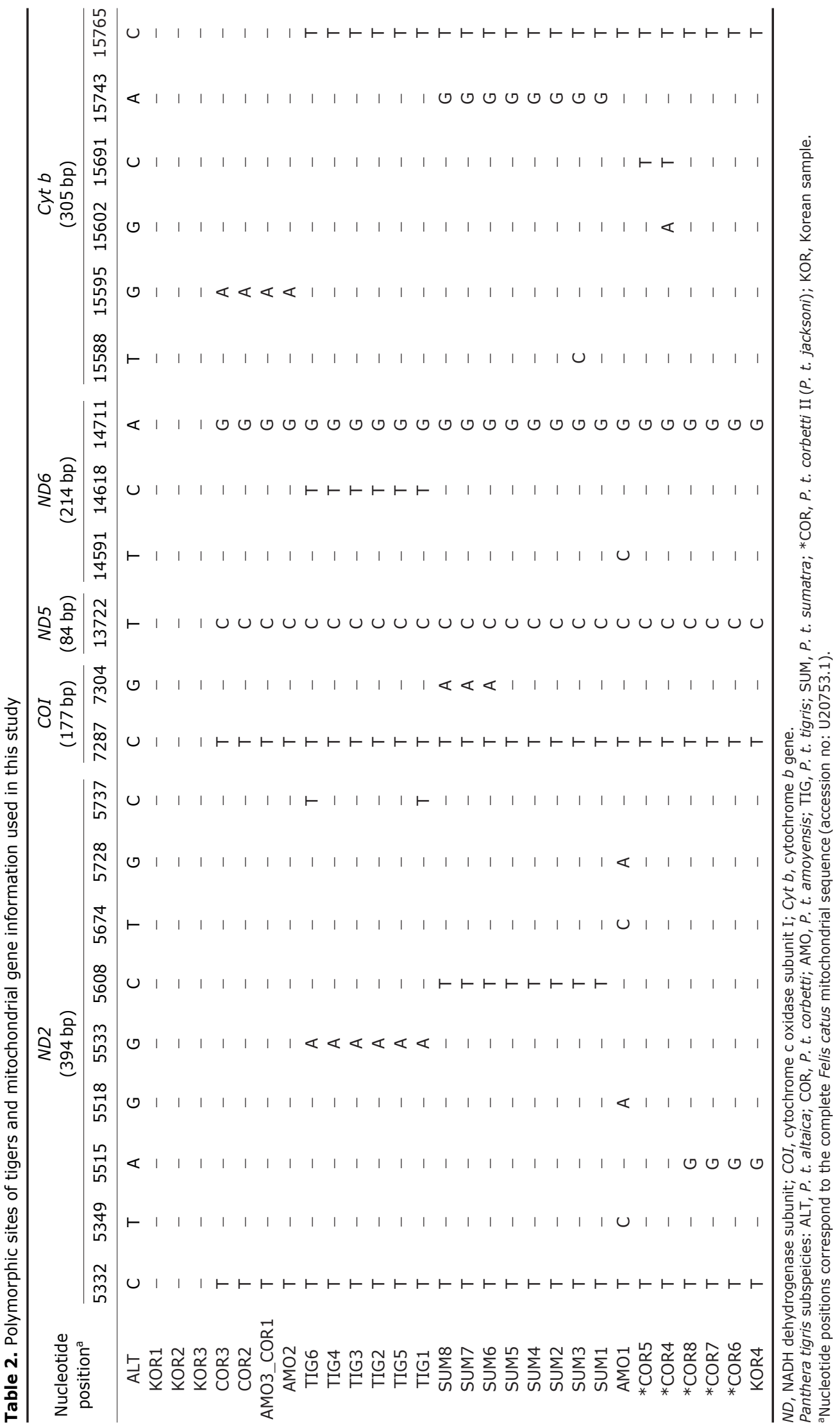


Mitochondrial gene sequences of tiger subspecies from a previous study were retrieved from GenBank for comparative phylogenetic analysis (Luo et al., 2004). Sequences were aligned using CLUSTAL_X (Thompson et al., 1997), and further modifications were made by eye using Geneious 5.3 (Drummond et al., 2011). Polymorphic sites were extracted using DNAsp v4.10 (Rozas et al., 2003). The most likely evolutionary model parameters were identified using the Akaike Information Criterion (AIC) in Modeltest v3.06 (Posada, 2008). The most suitable model of DNA substitution was $\mathrm{HKY}+\mathrm{G}$. An optimal phylogenetic tree was constructed using distance neighbor-joining method in PAUP version 4.0b10 (Swofford, 2002). Eight fragments were combined for a phylogenetic analysis. The robustness of the tree was evaluated by bootstrap resampling (1,000 random replications) (Felsenstein, 1985).

\section{RESULTS}

DNA was successfully recovered from bone powders of tigers that were collected in Korea around 100 year ago. Five segments (ND2, COI, ND5, ND6, and Cyt b) of mitochondrial

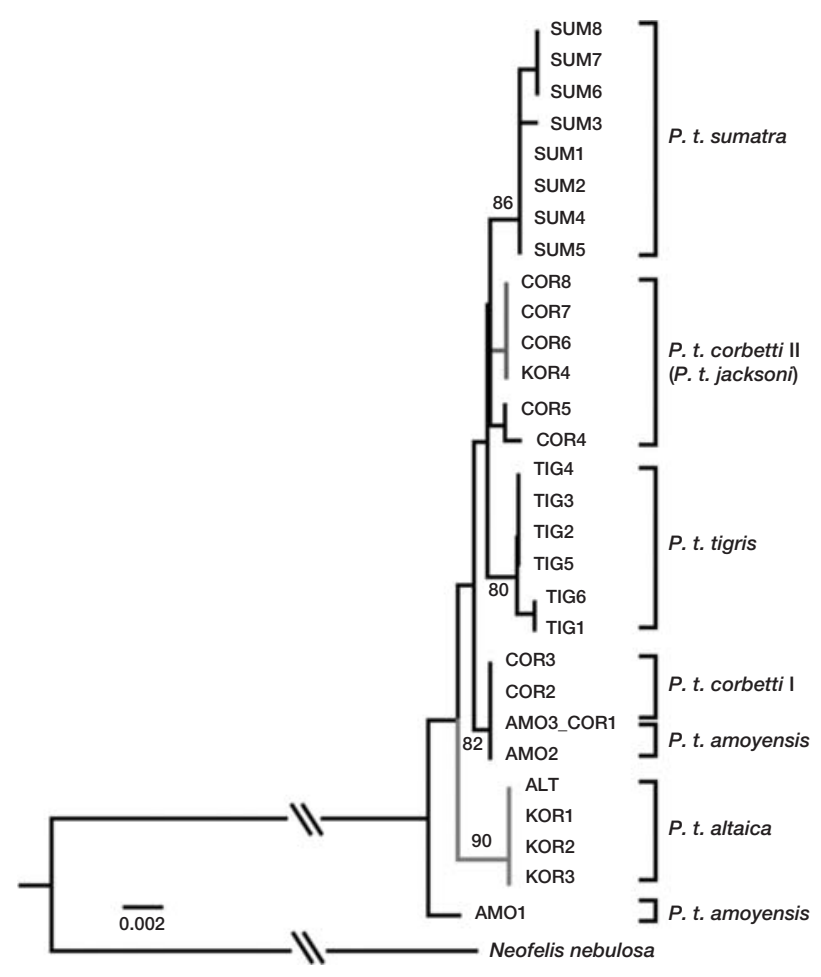

Fig. 1. Phylogenetic relationships of the Korean tigers using combined mitochondrial DNA. A distance neighbor-joining tree was constructed with 1,174 bp of mitochondrial DNA in PAUP version $4.0 \mathrm{~b} 10$. Node bootstrap values greater than $80 \%$ are shown.
DNA were amplified and sequenced from all samples using eight primer sets to yield a total of 1,174 base pairs including 22 subspecies diagnostic variable sites (Table 2) (Luo et al., 2004).

Analysis of the sequences revealed two haplotypes from the four individuals in this study. When compared to previously published sequences, one haplotype shared by three individuals (KOR1 from NMNS; KOR2 and KOR3 from $\mathrm{NMNH}$ ) was identical to the Amur subspecies, $P$. $t$. altaica (Table 2, Fig. 1). In contrast, the other haplotype (KOR4) matched a haplotype found in the Malayan tiger, $P$. $t$. jacksoni (Table 2, Fig. 1), which corresponded to COR6, COR7, and COR8 in Luo et al. (2004). The two haplotypes had five nucleotide differences.

\section{DISCUSSION}

Tigers are currently listed as an endangered species class I by the Ministry of Environment in South Korea. Although many people will not be convinced that tigers still survive on the peninsula without any scientific evidence, it is broadly believed by the public that they are not extinct. As the Korean tiger disappeared before the genetic techniques were widely employed, it was an unresolved question as to whether to classify the Korean tiger as an independent subspecies, $P$. $t$. coreensis, or as the Amur tiger, P. t. altaica. Our results help resolve the subspecies status of the Korean tiger relative to the Amur tiger.

We identified two mtDNA haplotypes from four 100-yearold specimens of Korean tigers. One haplotype was identical to that of the Amur tiger (P. t. altaica) (Fig. 2) while the other matched that of Malayan tigers (P. t. jacksoni) (Table 2, Fig. 1). It is surprising that the haplotype of Malayan tigers

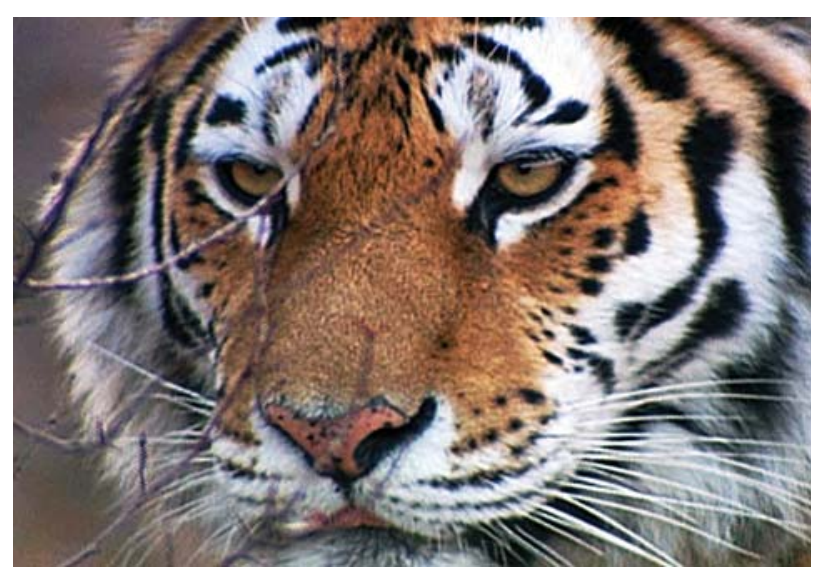

Fig. 2. Amur tiger (Panthera tigris altaica) in its wild habitat of Russian Far East (photo taken by Sooyong Park). 
was found in this study because it is highly unlikely that the Malayan tiger inhabited the Korean peninsula a century ago.

The surprising result can be explained by either 1) a mishandling of the specimens between 1902 or early 1903 when Dr. Smith and his hunter collected the samples and 1906 when they were donated by C. Hart Merriam to the NMNH on behalf of Dr. Smith (database of the NMNH) (Hollister, 1912; Chung, 1978), 2) mislabeling during 100 years of storage at the museum, or 3) cross-contamination during the experiment due to the nature of ancient DNA. The last source has the lowest possibility since all lab work was carried out in a dedicated laboratory for ancient DNA where the DNA of the Malayan tiger was not handled. However, there are reliable records showing that Dr. Smith, the collector of Korean tigers, caught the three tigers in Mokpo, Korea in 1902 or early 1903 and that these tigers were deposited at the National Museum of National History, USA (Hollister, 1912; Chung, 1978). Without further information on the specimens and their storage, it is not possible to verify the precise basis of the questionable results.

In conclusion, except for the individual identified as Malayan tigers, the results presented here suggest that the Korean tiger is not an independent subspecies, $P$. t. coreensis. Instead of considering the Korean tiger as a different subspecies, we recommend that it should be regarded as $P$. $t$. altaica. This conclusion is also supported by an ecological view as tigers can disperse approximately $400 \mathrm{~km}$ and their home range size of female is around $400 \mathrm{~km}^{2}, 1,300 \mathrm{~km}^{2}$ for male (Miquelle et al., 2005; Goodrich et al., 2010). In addition, it is unlikely that there has been a physical barrier to prevent dispersal of tigers in and out of the Korean peninsula.

The current population size of Amur tigers (P.t. altaica) is less than 600 due to several factors including loss of prey, habitat destruction/fragmentation, and over hunting for fur and Traditional Chinese Medicine (TCM) (Carroll and Miquelle, 2006). As our results show that the Korean tiger belongs to the Amur tiger, $P$. t. altaica, either captive or wild populations of the Amur tiger could serve as a source population for the restoration of the Korean tiger in the future. It may also be relevant that the former Caspian tiger has been shown recently to be near indistinguishable in genetic terms from P. t. altaica raising the prospect of tiger restoration of Caspian tiger habitat with re-located Amur Tiger founders (Driscoll et al., 2009, 2011). As the Amur tigers have the potential to be source populations for both Korean and Caspian tigers, further emphasis needs to be placed on the conservation of the Amur tigers in Russian Far East. Therefore, in order to preserve or restore the tigers in the Korean peninsula continuous effort is necessary for the conservation of the Amur tiger.

\section{ACKNOWLEDGMENTS}

We wish to thank National Museum of Natural History (NMNH), US and National Science Museum, Tokyo (NSMT), Japan for sample collection. We also thank Linda K Gordon, collection manager of the NMNH for help with providing samples. Thanks are also due to Hayatoshi Hirata of the NMNS for assistance with searching Japanese articles and information on Korean tiger remains and Sooyong Park for providing the photo of an Amur tiger.

\section{REFERENCES}

Brass E, 1904. Nutzbare Tiere Ostasiens. Pelz und Jagdtiere, Haustiere, Seetiere, Neudamm, p. 4.

Carroll C, Miquelle DG, 2006. Spatial viability analysis of Amur tiger Panthera tigris altaica in the Russia Far East: the role of protected areas and landscape matrix in population persistence. Journal of Applied Ecology, 43:1056-1068.

Chung YH, 1978. Synopsis for the conservation of nature and natural resources. Neaoe Publisher, Gwangju, pp. 1-422.

Dajokan, 1880. Consul general Maeda and consul Kondo ordered to work in Weonsanchin and Busanpo, respectively. In: Dajo Ruiten. Diplomatic relation and dispatching ambassador or consul. National Archives of Japan Press, 4:69 (in Japanese)

Driscoll CA, Luo S, MacDonald D, Dinerstein E, Chestin I, Pereladova O, O'Brien SJ, 2011. Restoring tigers to the Caspian region. Science, 333:822-823.

Driscoll CA, Yamaguchi N, Bar-Gal GK, Roca AL, Luo S, Macdonald DW, O'Brien SJ, 2009. Mitochondrial phylogeography illuminates the origin of the extinct Caspian tiger and its relationship to the Amur tiger. PLoS ONE, 4:e4125.

Drummond AJ, Ashton B, Buxton S, Cheung M, Cooper A, Duran C, Field M, Heled J, Kearse M, Markowitz S, Moir R, Stones-Havas S, Sturrock S, Thierer T, Wilson A, 2011. Geneious v5.4 [Internet]. Biomatters Ltd., Auckland, Accessed 14 Dec 2011, <http://www.geneious.com/>.

Endo K, 2009. Why had Korean tigers disappeared? Korean Studies Information, Paju, pp. 1-372.

Felsenstein J, 1985. Confidence limits on phylogenies: an approach using the bootstrap. Evolution 39:783-791.

Goodrich JM, Miquelle DG, Smirnov EN, Kerley LL, Quigley HB, Hornocker MG, 2010. Spatial structure of Amur (Siberian) tigers (Panthera tigris altaica) on Sikhote-Alin Biosphere Zapovednik, Russia. Journal of Mammalogy, 91: 737-748.

Hollister N, 1912. A new musk-deer of Korea. Proceedings of the Biological Society of Washington, 24:1-2.

Kim DJ, Lee H, 2011. A study on change in the relation between Korean people and Korean tiger in the Joseon Dynasty. The Ho-Suh Historical Association, History and Discussion, 58:155-185.

Luo SJ, Johnson WE, Martenson J, Antunes A, Martelli P, Uphy- 
rkina O, Traylor-Holzer K, Smith JLD, O’Brien SJ, 2008. Subspecies genetic assignments of worldwide captive tigers increase conservation value of captive populations. Current Biology, 18:592-596.

Luo SJ, Kim JH, Johnson WE, van der Walt J, Martenson J, Yuhki N, Miquelle DG, Uphyrkina O, Goodrich JM, Quigley HB, Tilson R, Brady G, Martelli P, Subramaniam V, McDougal C, Hean S, Huang SQ, Pan W, Karanth UK, Sunquist M, Smith JLD, O’Brien SJ, 2004. Phylogeography and genetic ancestry of tigers (Panthera tigris). PLoS Biology, 2:e442.

Miquelle DG, Stephens PA, Smirnov EN, Goodrich JM, Zaumyslova OY, Myslenkov AE, 2005. Tigers and wolves in the Russian Far East: competitive exclusion, functional redundancy and conservation implications. In: Large Carnivores and the Conservation of Biodiversity (Eds., Ray JC, Berger J, Redford KH, Steneck R). Island Press, Washington, DC, pp. 179-207.

Morell V, 2007. Wildlife biology: can the wild tiger survive? Science, 317:1312-1314.

Posada D, 2008. jModelTest: phylogenetic model averaging.
Molecular Biology and Evolution, 25:1253-1256.

Rozas J, Sánchez-DelBarrio JC, Messeguer X, Rozas R, 2003. DnaSP, DNA polymorphism analyses by the coalescent and other methods. Bioinformatics, 19:2496-2497.

Swofford DL, 2002. PAUP* Phylogenetic Analysis Using Parsimony (*and other methods). Version 4. Sunderland, MA.

Thompson JD, Gibson TJ, Plewniak F, Jeanmougin F, Higgins DG, 1997. The CLUSTAL_X windows interface: flexible strategies for multiple sequence alignment aided by quality analysis tools. Nucleic Acids Research, 25:4876-4882.

Tilson R, Defu H, Muntifering J, Nyhus PJ, 2004. Dramatic decline of wild South China tigers Panthera tigris amoyensis: field survey of priority tiger reserves. Oryx, 38:40-47.

Tilson R, Nyhus P, 2010. Tigers of the world: the science, politics, and conservation of Panthera tigris. 2nd ed. Elsevier, London, Burlington, San Diego, pp. 1-552.

Received December 11, 2011

Revised January 11, 2012

Accepted January 13, 2012 